\title{
An Assemblage of Decoloniality? Palestinian Fellahin Resistance and the Space-Place Relation
}

\author{
MARK MUHANNAD AYYASH \\ Mount Royal University, Canada
}

\begin{abstract}
This paper examines how fellahin resistance beginning in the early parts of the $20^{\text {th }}$ century interacted with the Zionist settler-colonial project, focusing on how this resistance operated on a complex understanding of the relation between the fixity of place and flux of space. Thinking this resistance alongside theories of colonial occupation as well as Deleuze and Guattari's theory of assemblage and the smoothstriated mixture of space, I argue that following the complex interplay between space (flux) and place (fixity), as opposed to resolving it, may yield a promising pathway in Palestinian, and perhaps global, decolonial resistances today. This can be observed in the contemporary resistance of Palestinian fellahin in the village of Bil'in, whose repertoires of action constitute an assemblage, both spatially and temporally. I argue that one of the important lessons found in the discourse and actions of Bil 'in activists is that land is autonomous of human desires and plans, of ethno-national ideological projects. Opening politics to the insight that the flux of space cannot be tamed within a bounded nation-state produces a decolonial resistance that sees the displacement of people from the land as the displacement of life itself.
\end{abstract}

KEYWORDS assemblage; space-place; Palestinian fellahin; decoloniality

In 1989, Edward Said explained his support for the Palestine National Council's (PNC) 1988 decision to accept United Nations Resolutions 181 (partition of Palestine to form a Jewish state and an Arab state), 242 and 338 (enforcing the borders of pre-1967 War). Said (1989, p. 15) characterizes the PNC's decision as an "emphatic transformation from liberation movement to independence movement." Prior to this decision, the PNC officially held the goal of liberating all of Palestine and allowing all Palestinian refugees and exiles to return to the land from which they were expelled in the 1948 War. This "break with the past," as Said puts it (1989, p. 17), was a difficult decision to make, filled with uncertainty. Yet, it was a sacrifice that was 
necessary for the sake of advancing the rights of the Palestinian people and the cause of peace and justice in the region (Said, 1989, p. 19). In accepting the UN Resolutions, the PNC accepted the establishment of the Israeli state, renounced "terrorism," and declared the establishment of a Palestinian state.

Aware of the complexities and subtleties of the conflict, Said (1995) viewed the injustice of the Palestinian case in clear terms: Palestinians were and are struggling against forceful expulsion from their lands which rendered them exiles, refugees, second-class citizens, and occupied peoples. By calling the PNC's decision a break - an emphatic transformation - Said seems to assume that the PNC's leadership (guided by Yasser Arafat's Fatah) shared his view of the struggle prior to the 1988 decision. $^{2}$ But as Rashid Khalidi's (1997) seminal work on Palestinian identity and the nationalist movement indicates, various Palestinian leaderships across history have never properly addressed the losses suffered by the Palestinians. Khalidi chronicles three stages in how Palestinian identity came to be constituted in the nationalist movement (for a summary of the stages, see Khalidi, 1997, pp. 193-194). His argument makes clear that, throughout these stages, Palestinian identity came to be understood as essentially tied to a specific boundary that is, like that of other modern nation-states, relatively recent in the making (Khalidi, 1997, p. 194). This approach to identity and the nation-state posits the two as essentially connected to one another in a symbiotic relationship where the nation-state supports and houses a fixed national identity, while this identity is seen to stretch simultaneously, in seamless continuity, to a historical point prior to the formation of modern boundaries (Khalidi, 1997, p. 194). For Khalidi (1997, pp. 205-209), this approach overlooks some of the important contradictions and complex questions surrounding Palestinian identity, which mostly revolve around various internal struggles (socio-economic, political, and cultural) and the continuing dispersal of the Palestinian people in the contemporary era. ${ }^{3}$

Following Khalidi, I do not suggest that the Palestinian leadership - in all its varied forms - has consciously or intentionally betrayed the Palestinian struggle. While Khalidi (1997) focuses on distinctive features of the Palestinian leaderships in explaining their failure to address Palestinian losses - most notably, the discursive trope of "failure as triumph" - I want to

\footnotetext{
1 The PNC's declaration made a distinction between legitimate violent resistance to defend against occupation and "terrorism" defined as an "indiscriminate violence whose aim is to terrorize civilians" (Said, 1989, p. 18).

${ }^{2}$ PNC members like George Habash of the Popular Front for the Liberation of Palestine shared Said's viewpoint and opposed Fatah's strategies and visions.

${ }^{3}$ Ghanem (2013) attempts to trace the transformations within Palestinian Nationalism on the question of the state, most notably the move from an "ethnic" to a "secular" form of nationalism during the 1960s-1970s, and more recently towards the "two-state solution." Regardless of these shifts, Palestinian Nationalism always remained tied to a conceptual paradigm wherein national identity and the nation-state are symbiotically related. It is this paradigm itself that I want to critique from the outside as it were, even as I remain cognizant and appreciative of the differences (ethnic, secular, etc.) that exist within this paradigm.
} 
explore whether the leaderships' fundamental conceptions of space and place in the form of the nation-state and its concomitant essentialized identities have prevented them from speaking to the injustices and losses of the Palestinian people. It is perhaps in their failure to present a decolonial alternative to the colonial conception of space and place that they were always bound to replicate the colonial system and indeed support it - just as Said feared in 1989 (pp. 17-22) and then came to observe in the 1990s.

One of the major pitfalls of many anti-colonial struggles is the tendency to oppose the colonial authority by repeating the colonial logic of occupation and state-building. Such a dynamic can be observed in how the Palestinian Authority (PA), in its official position on the two-state solution, has centered its entire strategy of resistance on the creation of a bounded Palestinian nation-state. Although this is certainly an understandable foundation for struggle, I maintain that the centering of state-building has historically effaced, and continues to efface, the suffering and resistance of Palestinians. To illuminate this point, the paper examines how fellahin resistance beginning in the early parts of the $20^{\text {th }}$ century interacted with the Zionist settler-colonial project. ${ }^{4}$ In their resistance, the fellahin operated on a conception of land that was very different from the Zionist/Israeli and Palestinian nationalist conceptions, a conception that may be identified as decolonial. The term "decolonial" is understood here primarily as heeding Mahmood Mamdani's (2001, p. 664) challenge for scholars to disentangle that symbiotic relationship between a fixed identity and the nation-state; or, to:

...go beyond the conventional thought that the real crime of colonialism was to expropriate the indigenous, and consider that colonialism perpetrated an even greater crime. That greater crime was to politicize indigeneity, first as a settler libel against the native, and then as a native self-assertion.

In challenging the settler-native distinction and the identification of either the "settler" or the "native" (as exclusive of one another) with the legal/political structures of the nation-state, a decolonial alternative to colonialism would break apart from the legacy, grammar and institutions of colonialism (Mamdani, 1996). Therefore, while the anti-colonial resistance of the Palestine Liberation Organization (PLO) or the Palestinian Authority (PA) rests on the statist project, the decolonial resistance of the fellahin rests on an alternative model of social organization, which challenges modernist conceptions of the state and its naturalizing of the relationship between the state and an essential/fixed national identity. This kind of decoloniality

\footnotetext{
${ }^{4}$ As there are differences between European peasantry and the Arab fellahin, I will use the term fellahin. As Abufarha puts it, "a peasant in European culture is a farming worker with little or no land ownership. The fellahin of Palestine are rural farming communities with communal shared ownership of the land, which they cultivated according to communal traditions. They owned the land and the means of production (working animals and tools)" (2008, p. 367). I later discuss the different notion of "ownership" within these communities.
} 
(which I do not claim exhausts the definition of the decolonial and all of its potential paths and dimensions) can be observed in the contemporary resistance of Palestinians in the village of Bil'in, where activists conceive of the land as autonomous of human desires and plans, of ethno-national ideological projects. These activists advance and employ what may be called a decolonial resistance that sees the displacement of people from the land as the displacement of life itself; that is, life is not something that occurs on the land, as separate from the land, and neither does the land exist in complete detachment from life. Rather, even as the land exceeds our ability as human beings to understand and fathom it, our very life is viewed as part and parcel of the land: what I term land as life.

In temporally and spatially tracing decolonial resistance through the notion of land as life, the paper employs assemblage thinking. The concept of assemblage serves as a theoretical alternative to "organic totalities," the latter of which posits that the parts and the whole are guided by relations of interiority, a seamless totality whereby the component parts relate to one another only in so far as they belong to the whole and are primarily defined by the whole in which they exist (DeLanda, 2006, p. 9). In contrast, assemblages are "wholes characterized by relations of exteriority," whereby parts can move across different assemblages without necessarily losing the autonomy of their terms or properties (DeLanda, 2006, pp. 10-11). The concept's openness to the flux of social phenomena has made it appealing to the study of social movements, as the latter tend to be an ever-changing, fluctuating and unpredictable set of events and actions. But unlike efforts to qualify the application of assemblage thinking to the study of movements by affixing terms to assemblage, such as "global assemblages" (Ong \& Collier, 2005) or "translocal assemblages" (McFarlane, 2009), I prefer to follow Gilles Deleuze and Félix Guattari's own articulation of assemblages as having both spatial and temporal dimensions. Relations of exteriority already suggest a movement that can take place across small and large swathes of space and time, and consequently there is no need to delimit space and time when it comes to assemblage thinking. The main advantage of this approach is twofold: (a) it avoids binary distinctions between local and global, as well as the sharp distinctions of past-present-future across a continuum, which inevitably feature in attempts to qualify the concept of assemblage with delimited notions of space (e.g., global) and time (e.g., continuum); and (b) it proposes the co-existence of temporal and spatial dimensions within assemblages, thus allowing for an analysis of specific contemporary practices of resistance (in Bil'in) within a much deeper temporal reading of that resistance, while concurrently expanding the spatiality of these temporal moments.

The paper also demonstrates how assemblage thinking can be fruitfully combined with decolonial modes of thought and politics. As Bignall and Patton (2010, pp. 6-7, 9-10, 17) argue, the Deleuzian emphasis on transformation, creation of alternative worlds, and horizontal conceptual 
movements across plateaus (as opposed to theoretical frameworks that attempt to vertically capture things within concepts) can constructively engage with postcolonial attempts to counter the ways in which the colonial claims to fix the colonized. Indeed, Deleuze and Guattari were particularly supportive of the Palestinian decolonial struggle against colonial modes of capturing their territories, which is not surprising given that Deleuze and Guattari's concepts of "movements of de/reterritorialisation describing a conceptual politics of capture and relative liberation...resonate with themes and issues pertinent to postcolonialism" in general and the Palestinian case in particular (Bignall \& Patton, 2010, p. 3). ${ }^{5}$ By horizontally moving across the insights generated in assemblage thinking, colonial occupation and dispossession, and the everyday theorizing that occurs in and emerges from resistance, the paper seeks to generate a novel perspective through which we can view and examine the decoloniality of resistance. This paper does not adopt the conventional approach of theoretical analysis, as it does not seek to (a) transcendentally apply a theory to a case, (b) test an existing theory against a particular case, or (c) develop a testable set of theoretical postulates and predictions out of sporadic case-specific observations. Neither does it claim to offer an exhaustive look at the multiple dimensions of Palestinian fellahin resistance. Instead, the paper moves across varied theoretical insights generated in academic texts and resistance practices to locate and read a marker of decoloniality in the case of Palestine.

The analysis proceeds in three sections. First, the paper outlines the colonial conception of land that underpins the Zionist settler-colonial project. Combining Said's decolonial critique of the settler-colonial state and struggles against it with Deleuze and Guattari's related concepts of assemblage and the smooth-striated mixture of space, this section draws out how these ideas can reorient scholarly views of fellahin resistance towards the question of decoloniality. The second section explores the temporal depth of fellahin resistance and outlines the decolonial alternative conception of land that this resistance operates on. The third section follows the movement of this conception across temporal and spatial dimensions in the contemporary resistance of the villagers in Bil'in. The paper's analysis situates this particular conception of land as life as a component part of an assemblage called fellahin resistance - and as a marker of decoloniality in the case of Palestine.

\footnotetext{
${ }^{5}$ See also Burns \& Kaiser, 2012. The connections between Deleuze, Said, and the Palestinian struggle are also examined by David Huddart's chapter in that volume (in Burns \& Kaiser, 2012, pp. 76-95).
} 


\section{Colonial Occupation and Dispossession}

A well known difficulty of decolonial struggles is to launch a countermovement that is already based in and constitutive of an alternative worldview; to counter colonialism without falling back into the colonial logic or grammar. In his discussion of "resistance culture," Said (1994) helps us understand this dilemma in terms of the question of nationalism. Said (1994, pp. 209-210, 215-216) views decolonial resistance culture as vacillating across two general approaches: one that attempts to reconstitute and rebuild the destroyed and shattered community by reconstituting a fixed "precolonial" identity, and another where resistance to colonialism seeks to reconceive human history, liberation and community. The first approach is significant in raising a community's consciousness of its own subjection to colonial power. However, according to Said (1994, pp. 210-214) it suffers from a significant shortcoming in that it ends up essentializing the identity of the colonized along racial and ethnic lines established by colonial grammar and institutions.

This shortcoming is addressed in the second approach of resistance culture, where the idea of resistance, "far from being merely a reaction to imperialism, is an alternative way of conceiving human history" (Said, 1994, p. 216). Most significant is how such cultural forms break down the barriers between cultures and traverse across not just "native" or colonized cultures but across European and colonizing cultures as well. Here is found a sort of playful exploration of the interconnectedness between these cultures in a way that also highlights the features of domination, exploitation, and marginalization that mark the relationship between the imperial centers and the territories of the colonized. Consequently, a significant feature of this approach "is a noticeable pull away from separatist nationalism toward a more integrative view of human community and human liberation" (Said, 1994, p. 216). Walking a tightrope that neither dismisses nationalism and the need for national self-determination nor places the establishment of a nationstate as the pinnacle achievement of decolonial resistance, Said (1994) makes clear two integral points. First, the greatest promise of decolonial resistance is the realization that human liberty can only be achieved by people working in concert with one another contrapuntally, across the nationalistic divides that separate us, and for the sake of building a truly integrated community based on equality and justice. Second, it is not nationalism as a whole that is problematic to decolonial resistance, but rather a certain kind of nationalism that arises out of an essentialized understanding of the national identity (Said, 1994, pp. 216-220, 258-259, 276-279).

From the insights generated by Said, the question then becomes: how can decolonial movements claim and reclaim a people's place without essentializing the people or the place, or the relation between them? In fixating on the establishment of a nation-state that is built on essentialist views of Palestinian identity, the Palestinian leadership fails to adequately 
address this question (Said, 1999). Furthermore, as previously mentioned in relation to Khalidi's (1997) work, this question is complicated for Palestinians by virtue of the people's dispersal; the varied spatial standpoints of Palestinians lead to sometimes radically different understandings of place (e.g. the differences in how Palestinian citizens of Israel and Palestinian refugees in Lebanon may view the lands of pre-1948). To account for this dispersal, I suggest that the question of place must be examined in its entanglement with a conception of space that is understood in this paper as flux, following Deleuze and Guattari.

Deleuze and Guattari distinguish between nomadic speed in "smooth" space (absolute movement in-between points that subordinates the points to the autonomy of the in-between) and sedentary movement in "striated" space (where only reproducing established movements between rigid points occurs) (1987, pp. 380-831, 478). Even though distinguished and opposed particularly in the state form, which is disposed towards absolute striation of space (Deleuze \& Guattari, 1987, p. 386), the relation between smooth and striated space is one of mixture, as smooth space can sometimes be "translated" and "transversed" into striated space, and striated space can sometimes be "reversed" and "returned" to smooth space (Deleuze \& Guattari, 1987, pp. 474-475). The mixture, which appears in diverse assemblages of metamorphosis, can be liberating and it can be oppressive, but the point for Deleuze and Guattari is that the opposite sides of the relation are always mixed in that neither side can ever exhaust or completely eliminate the other (1987, pp. 478-482, 500). This relation can thus be referred to as an agonism.

Taken as a whole, this discussion of assemblage thinking presents a useful conceptual apparatus as a starting point for the analysis of decolonial resistance against the settler-colonial state: I understand the space-place relation as one that consists of an agonism between the flux of space ( $a$ la nomadic smooth space) and the fixity of place (à la sedentary striated space). In this agonism, the flux of space is itself a danger to the state apparatus because it reveals the very foundation of the state, which is nothing other than the state's translation of the flux of space. There is no absolute law or universal foundation operating underneath the formation of the state; there is no essential connection between the state and the space upon which it is founded. The flux of space is a constant reminder that the state was instead formed on brute relations of force, that the state must hide from itself in order to secure itself. And the state attempts to evade the flux of space by striating space, by making it predictable, governable, and ordered - in short, by fixing it as place.

In relation to this smooth-striated mixture, I am specifically interested, first, in how the state attempts to settle the agonism once and for all by striating and fixing all space as place, and sees its survival as dependent on successfully achieving this settlement. This is especially acute in the case of the settler-colonial state where the founding violence of the state is 
unconcealed at the moment of founding, and is thus more difficult to hide in subsequent periods of the state's history, although concealing this violent founding is precisely what every settler-colonial state seeks to achieve (Coulthard 2014, pp. 15-17). As Glen Coulthard (2014) asserts, the settlercolonial project first establishes, through force, a relation of domination that dispossesses Indigenous peoples from their lands. It is then "structured into a relatively secure or sedimented set of hierarchical social relations that continue to facilitate the dispossession of Indigenous peoples of their lands and self-determining authority" (Coulthard, 2014, p. 7, emphasis in original). The concealment of violence in the social, cultural and political arenas is simply the continuation of the effects of the brute violence of founding. Both the concealment and the founding violence thus strive to striate the flux of space. What is perhaps unique about the Zionist settler-colonial project is that this feature of striating the flux of space was present in the Zionist movement at the moment of its inception, even before its founding violence.

Joseph Massad's (2006) work suggests that the Zionist settler-colonial project emerged from the flux of the Jewish Diaspora for the purpose of striating that very flux (see also Gorny, 1987; Likhovski, 2010; Salamanca, Qato, Rabie \& Samour, 2012). Underpinning this settler-colonial project is what Massad (2006) usefully formulates as a sort of space-time compression. According to Massad (2006, pp. 39-40), the Israeli colonial/"post-colonial" space-time is fundamentally concerned with transforming what are conceived as "weak" and "wandering" diasporic Jewish bodies into "strong" and "nationalist" post-diasporic Jewish bodies. In this compression, diasporic Jewish bodies, as well as Palestinian and Mizrahi bodies that present a challenge to the hegemony of the Israeli space-time are therefore viewed as mere glitches in the system that must be reprogrammed or else face expulsion and/or political and cultural extinction (see also Lavie, 2011). To somewhat reformulate Massad's (2006) insights using the language of Deleuze and Guattari, his work highlights how Zionism is fundamentally opposed to the flux of movement, to nomadic speed cutting across striated space. Seen through this lens, the logic of occupation, as formulated in Zionism, is posited as the response to the flux of space (and the violences endured in the diasporic condition; we should not discount the gravity of the context in which Zionism emerged and attempted a response), a flux that is embodied in diasporic Jewish existence. And it is in this response that we find a view of the land as a place to be captured, owned and governed, bounding space within a place called the nation-state, dispersing Palestinian bodies and creating a compression in which these bodies in their dispersal, in their very flux, appear only as threats to the striation of space.

During the early parts of the $20^{\text {th }}$ century, the fellahin were at the forefront of Palestinian resistance and sought to oppose the processes of their dispossession. I argue that, contra the discourse of Palestinian nationalism, their resistance to the Zionist settler-colonial project operated on a complex understanding of the relation between the fixity of place and flux of space. 
This resistance presented and operated on a kind of smooth-striated mixture that was very different from nation-state building projects. This mixture is a critical component of the assemblage called fellahin resistance.

Following Deleuze and Guattari (1987, p. 406), I understand an assemblage as "every constellation of singularities and traits deducted from the flow" and acknowledge that an assemblage may group itself into "extremely vast constellations" which differentiate the phylum or the flow, thus "introducing selective discontinuities in the ideal continuity of matter-movement." I do not view the fellahin as a homogenous group with identical/essential identities, worldviews, beliefs and values (thus avoiding the dangers that Said raises). At the same time, I posit the resistance of the fellahin as constitutive of a large constellation that includes a set of interactions with Zionist ideas, values, beliefs and projects. One of the main components of this constellation, of this assemblage that I call fellahin resistance, is that space never becomes the absolute boundary of itself within a bounded place.

\section{Fellahin Resistance}

In Ottoman-ruled Palestine, large parcels of land were owned by absentee landlords - mainly Turkish officials and non-Palestinian Arabs (Khalidi, 1997, pp. 111-114) - who were only interested in profit and treated the fellahin that had been there for generations as tenants that live on and cultivate the lands (Yazbak, 2000, p. 95). ${ }^{6}$ Beginning in the late 1800s, but especially gaining pace in the early 1900 s, Zionist organizations and groups started to purchase lands from the absentee landlords. These organizations did not buy the land as an investment, but for the sake of an ideological project that sought to displace the fellahin, remove them from the purchased lands and create a Jewish state. When they were not expelled, the fellahin were often forced to become agricultural laborers (Khalidi, 1997, pp. 98-99), and such activities led to the worsening of already dire economic conditions for the fellahin (Yazbak, 2000, pp. 100-102).

The displacement of the fellahin put them at the forefront of the conflict between the Palestinian people who already inhabited the land and the Zionist enterprise that sought to uproot them. This fundamental conflict over land led to the first cases of armed resistance against Zionist settlers as early as 1886 (Khalidi, 1997, pp. 102-106). With the mounting pressure of increased Zionist settlement and the "hopeless ineffectiveness of [the Palestinian elite's] leadership of the national movement" (Khalidi, 1997, pp. 186-189), the dispossessed set themselves on the path of active resistance: the Arab

${ }^{6}$ In the period from the 1900 s to the 1930 s, approximately $70 \%$ of the Palestinian population consisted of rural communities, which largely identified as fellahin (Swedenburg, 1990, p. 27). The majority of the fellahin held onto a fierce sense of autonomy from any authority that tried to interfere with their daily lives on the land, and they developed strategies against Ottoman reforms of land ownership laws (see Doumani, 1995, pp. 131-134, 149-181). 
revolt of 1936-1939. This revolt consisted of armed and unarmed actions, and although it was promising, it was ultimately crushed by the British; this set the stage for the greatest Palestinian defeat in the Nakba (the catastrophe) of 1948 (Khalidi, 1997, pp. 189-190).

For Khalidi, despite the clear fact that the violent acts of resistance simply led to massive loss of life and never accomplished much in terms of addressing the losses of the fellahin, the Palestinian leadership consistently posed these violent acts as triumphs of the Palestinian national cause and selfdetermination. This is especially the case in the years after 1948, when Palestinian groups such as Fatah, and the PLO in general, began in the 1960s, to articulate past and present defeats as triumphs, arguing that historical acts of violent resistance showed the "'correct' path of popular armed struggle against the British and the Zionists" (Khalidi, 1997, pp. 195, 196, 199). Such accounts, Khalidi (1997) argues, worked to seamlessly connect the ongoing armed struggle of the PLO with these past events of violent revolt, and consequently painted the PLO's own failures as triumphs. This discourse essentially masks "the poor political calculations, and the disorganization, confusion, and leaderless chaos on the Palestinian side" that were the marked features of all Palestinian defeats and setbacks, from the 1930's onwards (Khalidi, 1997, pp. 196, 199). Khalidi (1997, pp. 177-209) concludes that a more accountable, organized and visionary leadership is needed to address the very difficult and multi-faceted Palestinian problem. In a Fanonian mould, Khalidi (1997) argues that such a leadership would re-direct the energies of the people towards the creation of a strong democratic national state.

But why hasn't this leadership emerged in the case of Palestine? It certainly is not due to a lack of creative, ethical, visionary, selfless and dedicated leaders in the Palestinian community. Scholars have put forth a number of answers to this question, which include the influence of external powers (e.g. Sayigh, 1997/2007), the Israeli strategy to create a chaotic political system (e.g. Gazit \& Brym, 2011), deep internal divisions (e.g. Swedenburg, 1990), and power-hungry corrupt Palestinian leaders who try to eliminate and silence dissent (e.g. Massad, 2006, pp. 104-113). I am not disputing these elements, but I argue that there is perhaps a deeper reason for the failure of this ideal, yet not impossible, Palestinian leadership to emerge: Palestinian nationalist discourse effaces the fellahin conception of space-place rather than leading the struggle through this conception. The national liberation discourse poses the fellahin less as social actors and historical agents than as a national signifier that denotes the loss of Palestinian land and the inevitable loss of all Palestinian lands should Palestinians not unite under the banner of Palestinian Nationalism (Swedenburg, 1990, pp. 18-19). ${ }^{7}$

${ }^{7}$ The betrayal of the fellahin resistance by Arab and Palestinian political leaderships is an observation that is not lost on the fellahin, particularly to the generation that followed the Nakba (Sayigh, 1979/2007, pp. 4-5, 14).

Studies in Social Justice, Volume 12, Issue 1, 21-37, 2018 
Such a signification effaces not just the agency of the fellahin, but also the idea that when the fellahin revolted, they held on to a notion of land that was very different from the Ottoman authorities' or Zionist views of the land. The fellahin understood the land in the sense that they knew the land's geographies, tendencies, fertilities, every rock and plant, its smell and taste, its very movement or flow (à la Deleuze and Guattari's smooth space). Simultaneously, they knew the land in the sense of hosting the birth of a child, the sights and sounds of festivals, of weddings and funerals, of stories of love, courage, cowardice, and various collective endeavors of success and failure (Doumani, 1995, pp. 27-31, 52-53, 156-157). In short, they knew the land as a kind of receptacle of human life at the same time that this receptacle had a life and movement of its own.

This is not at all a romantic view but one that is shown in oral traditions and in research on oral histories. ${ }^{8}$ Most critical for this analysis is that for the fellahin nobody "owned" the land in the sense of individual ownership of property within a capitalist political economy, or within the bounded framework of a nation-state; most fellahin never comprehended such notions of land ownership (Sayigh, 2007, pp. 27-28). Instead, people had "rights" to the land in the sense that it belonged to a collectivity (on the village level) that knew the land, cultivated it, and held it "on a [hereditary] usufruct basis known as miri" (Ruedy, 1971, p. 122; also see Davis, 2011, pp. 113-121). Life and land were inseparable for the Palestinian fellahin, and only those who best knew the land lived on it, and they lived on it because they knew it best, were part of it, as it was a part of them. ${ }^{9}$

A brief illustration is found in the writing of village books, which attempt to record Palestinian oral histories of destroyed villages so that they can be passed down to coming generations. In her analysis of interviews with authors of the village books, Davis (2011) argues that authors often found lacking the official Palestinian historiography, which consisted of British documents, political agreements, official statistics on land, demography, socio-economic class and so on. For the village books' authors, and the villagers themselves who are largely of a fellahin background, these official accounts lacked "any sense of the people of the village, the village space, its social history, and the sentiments of those who lived and worked and married and raised children in the village" (Davis, 2011, p. 70). It is not that statistical information is not useful for villagers and the books' authors, but that state authorities, such as the British, collected such information about the villagers to satisfy and meet the state's instrumental purposes (Davis, 2011, pp. 135136). Therefore, such information can never speak to what actually matters

\footnotetext{
${ }^{8}$ See Sayigh's (1979/2007) classic study, and Davis (2011) for how Palestinians have in recent times recorded oral histories in the "village books."

${ }^{9}$ This view of land is not unique to the Palestinian fellahin, or to the majority of Palestinians, who continue to share it (Abufarha, 2008, pp. 362, 366). For example, see Coulthard's examination of the anticolonial struggle of Indigenous peoples against the Canadian state (2014, pp. 14, 64-66, 77-78, 170-176).
} 
for the villagers: life on the land. And just as this type of information cannot speak to the life lived on the land, it cannot speak to the loss of the land. The statistics on lands lost, villages destroyed, people displaced, wealth stolen, and so on cannot capture the loss that the fellahin experienced. The loss of land is unspeakable because it is the loss of life itself, because of the unspeakability of death itself; and it is this loss that the fellahin revolted against.

Over the years, the PLO has morphed into the PA, which largely ignores the 1948 refugees' right of return and in doing so does not represent the Palestinians of pre-1948 (among others). The disenchantment with the PA over the question of representation and many other issues (e.g., the economy) has given rise to a fresh wave of grassroots politics that Sunaina Maira associates with "Jil [Generation] Oslo," which seeks to resist colonial occupation, not on the traditional models of political parties and established political entities like the nation-state, but rather on the basis of a decolonial view of the land in that it connects Palestinian resistance to global indigenous struggles highlighting the refusal of the Palestinians to disappear from the land (Maira, 2013, pp. 31-63, 187-192). In the next section, I examine how the movement of what I am proposing is a decolonial conception of land carries within it a property or an element of decoloniality that reconstitutes a new assemblage of fellahin resistance in the village of Bil'in.

\section{Bil'in}

In their study of popular unarmed Palestinian resistance, Marwan Darweish and Andrew Rigby (2015) illustrate the wide range of Palestinian acts of protest over the last 100 years or so. They situate activism in the village of Bil'in within the "resurgence of popular resistance" that occurred post-Oslo, from roughly 2002 onwards. Darweish and Rigby (2015) trace this resurgence to the construction of the Wall that acted as a physical barrier between the West Bank and Israel and led to the annexation of Palestinian land, which many villagers resisted through a variety of unarmed actions (Darweish \& Rigby, 2015, pp. 71-72). ${ }^{10}$ Early in 2005, the village of Bil'in became the focus of resistance against the Wall, and although Bil'in was not alone in its actions, it has garnered the greatest international attention.

Bil'in is a small village of 1,900 people, $12 \mathrm{~km}$ west of Ramallah. The majority of the land is agricultural and is known for its olive trees. A large number of the villagers identify as fellahin. To respond to the annexation of nearly $60 \%$ of their lands and the uprooting of their olive trees, the villagers formed a Popular Committee to guide their unarmed resistance for freedom

\footnotetext{
${ }^{10} \mathrm{I}$ am not proposing that statist colonial and anti-colonial action is always violent and that decolonial non-statist action is always non-violent. Unarmed action is simply the most accurate description of these actions (see Darweish \& Rigby, 2015).
} 
and liberty. The Chair of the Popular Committee, Iyad Burnat, stated in a 2014 interview that the Committee decided early on that a Palestinian Intifada is not going to be enough in securing their freedoms. Instead, their goal was to create a "Global Intifada," one that brings together people from across the world in the service of freedom and justice (Kerr, 2014). In this sense, their repertoires of action open up to vast spatial dimensions that operate not only on the level of action, but also on the level of their goal, which is a decolonial and universal kind of freedom that connects disparate groups and struggles from around the globe without subsuming their differences.

This gesture towards the universality of freedom helps explain Bil'in's international prominence. Activists in Bil'in creatively campaign through various new media outlets in order to create awareness and to develop local and international alliances in their struggle against land confiscation. For example, to counter Israeli plans to uproot their olive trees, activists chained themselves to the trees using local support to secure the chains, invited international and Israeli media to attend their action, and had them all witness Israeli soldiers forcibly removing the chains and beating the activists. As one activist put it, the event displayed the "big contrast between our nonviolence and their violence!" (Darweish \& Rigby, 2015, p. 77; see also pp. 89, 92-93). In addition, I believe that there are, contrasted here, different modes of relationality - a contrapuntal relationality that thirsts for freedom versus the relationality of occupation. On the one hand, the activists embody both their relation to the land and to a global community: the whole scene is one of assemblage in that the chains act as an extension of the body revealing the body's connection to the olive tree which signifies a long-term rootedness to the land. Simultaneously, the chains, the most visible human-made object in the act, reach out from the body to the cameras, communicating to Israeli and global audiences that this image is about human relations. The chains signify the Palestinian fellahin's chained body under occupation at the same time that an invitation is offered for Israeli and global audiences to join the resistance in acts of solidarity. In contrast, the soldiers embody the blocking of such relations. The forcible removal of the chains serves to confirm the forcible chaining of the body, revealing the soldiers' efforts to disconnect the activists from the land (i.e., the chain symbolizes the shackles that restrict Palestinian lives on the land) and from a global community (i.e., forcible unchaining that moves the body away from the cameras).

In addition to these spatial dimensions, an assembling with the historical resistance of the fellahin is operative. When Burnat (Chair of the Popular Committee) was asked in an interview about support from the PA, his first reaction was laughter (Kerr, 2014). Maintaining a distance from the PA and official Palestinian politics is not a dynamic that is unique to Bil'in and is present in much of Palestinian activism today (Maira, 2013; Darweish \& Rigby, 2015). What is most interesting about Bil'in is that its distance from the PA is predicated on the desire to not lose sight of the land, and more to 
the point, life on the land, or the land as life. There are countless examples of this dynamic, but it is best exemplified in the following action: when confronted with the building of an illegal settlement on their lands (ruled illegal by Israeli law in this case), the Committee decided to build their own crude illegal settlement on the land and place Palestinian activists inside the illegal trailers.

There are three interconnected elements in this action: (a) the placement of the Palestinian body in the enclosure of the trailer, (b) the exposure of the groundless ground of the state's authority, and (c) the affirmative construction of a decolonial alternative. Placing the body in the trailer serves practical purposes, such as making it more difficult for soldiers to simply destroy/remove the structure. In a deeper sense, the enclosure of the occupied body communicates the chained and colonized condition of the village's body politic in a manner that is reminiscent of Ghassan Kanafani's Men in the Sun. In Kanafani's (1962/1999) novella, three Palestinian men are being smuggled into Kuwait in a small lorry. At each checkpoint the lorry passes, the three men are forced to move inside the empty water tank in the back of the lorry to evade the authorities. On the very last checkpoint there is a delay, which turns the tank into the three men's grave as they all die of suffocation. In the last few lines of the story, the lorry's driver asks a simple yet impossible question: "Why didn't you knock on the sides of the tank? Why didn't you say anything? Why?" (Kanafani, 1962/1999, p. 74) The simplicity of the question is self-evident; its impossibility lies in the fact that the addressees of the question are dead and therefore cannot deliver a final answer, instead opening the door for the "desert's echo" of the question leading to an infinite multiplicity of answers (Kanafani, 1962/1999, p. 74).

In enclosing themselves in the trailer, the activists are, in effect, posing this same question but reversing its direction. They are asking the soldiers and the Israeli audiences in particular: "Why didn't you knock on the sides of the walls?" Again, the simplicity is self-evident, but the impossibility here lies in the fact that the addressees of the question are not dead but must conceal the condition of death (the Nakba) upon which their very mode of life is founded. If the body of the Palestinian can be eradicated without in a sense ever being touched - to go back to Massad - then something must be placed in between the body of the colonizer and the colonized as a medium through which the Palestinian body cannot but be touched. As the colonizer seems to lean towards the striation of space in the striated-smooth mixture (the settlement), then a mock striation of that very form (i.e., the Palestinian illegal settlement on the land confiscated for Israeli illegal settlement) can force the colonizer to touch, as it were, the colonized. To come face-to-face and witness what the mirror reveals becomes unavoidable: the concealed condition of the settlercolonial state's founding, which - in addition to the Nakba and because of the question's openness to a multiplicity of answers and interpretations - also includes the flux of diasporic Jewish existence. 
The question - "why didn't you knock?" - thus reveals the groundless ground of the state's authority, which was not established on an absolute law or foundation but rather, to go back to Coulthard (2014), through brute relations of force. This move to the foundation of the state connects the plights of the villagers in the first decade of the $21^{\text {st }}$ century to the Palestinian displacement that began in the first decade of the $20^{\text {th }}$ century. By mocking the "legality" of their displacement, this simple action poses the problem of Palestinian dispossession on the terms of early $20^{\text {th }}$ century fellahin resistance: the displacement of life from land. This goes beyond the Israeli state and indeed challenges the PA's modus operandi of "legally" claiming the land for Palestine, the nation-state. In doing so, the activists are taking actions that lie outside of the normal methods of protest practiced by the PA and its supporters, be they political, legal or diplomatic.

In that sense, the activists create and construct the alternative world they want to inhabit. The crude rooms signify, in their contrast with the buildings that surround them, the absurdity of the colonial logic of occupation and the absurdity of launching a decolonial struggle that seeks to emulate this logic. There are of course multiple practical purposes in these displays such as garnering media attention and making present what is rendered absent. But I think that deeper than these effects, the stark contrast demonstrates that emulating and replicating the colonial logic will always favor the colonizer. But more so, even if the colonized reverse the hierarchical ladder, even if the Palestinians manage one day to build the secure and comfortable building, the contrast itself, as contrast, will remain. And that raises another difficult question: is that a struggle worth waging or is there another path of struggle? A decolonial path that is truly different from the colonial world that Palestinians and Israelis inhabit, albeit very differently?

I think one of the important lessons we learn when we open ourselves up to the flux of space is that land is no more Palestinian or Muslim or Christian than it is Jewish or Israeli. In this sense, the fellahin embodied a certain insight into space: that land is autonomous of our desires and wanting, of our ideological projects; that no ideological project justifies the displacement of people from the land, the displacement of life itself. It is perhaps the case that the fellahin embodied the flux of space in a paradoxically very localized and sedentary manner. Perhaps the decolonial alternative to the colonial state is not the often celebrated nomadic speed found in Deleuze and Guattari, but rather this complex relation between the fellahin's type of settlement of space and the movement or traversal of space, a combination of a kind of fixity and flux. Perhaps this is the direction of a decolonial politics that we need to engage with and better articulate, understand, and practice. And regardless of the outcomes in Bil'in, perhaps this decoloniality will scatter and move only to resurface and metamorphose into a new assemblage called fellahin resistance, an assemblage of decoloniality. 


\section{Acknowledgements}

I wish to thank the special issue editors for their critical comments, suggestions, and questions, as well as the participants at the Global Movement Assemblages Symposium for the vibrant and engaging discussions we had around this topic. Thanks as well to Studies in Social Justice for their editorial comments and corrections. Finally, I wish to thank Mount Royal University's Writing Space Program for providing me with time and support to edit the article.

\section{References}

Abufarha, N. (2008). Land of symbols: Cactus, poppies, orange and olive trees in Palestine. Identities: Global Studies in Culture \& Power, 15(3), 343-368.

Bignall, S., \& Patton, P. (Eds.) (2010). Deleuze and the postcolonial. Edinburgh, UK: Edinburgh University Press.

Burns, L., \& Kaiser B. M. (Eds.) (2012). Postcolonial literatures and Deleuze: Colonial pasts, differential futures. New York: Palgrave.

Coulthard, G. (2014). Red skin, white masks: Rejecting the colonial politics of recognition. Minneapolis, MN: University of Minnesota Press.

Darweish, M., \& Rigby, A. (2015). Popular protest in Palestine: The uncertain future of unarmed resistance. London: Pluto Press.

Davis, R. A. (2011). Palestinian village histories: Geographies of the displaced. Stanford, CA: Stanford University Press.

DeLanda, M. (2006) A new philosophy of society: Assemblage theory and social complexity. New York: Bloomsbury.

Deleuze, G., \& Guattari, F. (1987). A thousand plateaus: Capitalism and schizophrenia. (B. Massumi, Trans.). Minneapolis, MN: University of Minnesota Press.

Doumani, B. (1995). Rediscovering Palestine: Merchants and peasants in Jabal Nablus, 1700 1900. Berkeley, CA: University of California Press.

Gazit, N., \& Brym R. J. (2011). State-directed political assassination in Israel: A political hypothesis. International Sociology,26(6), 862-877.

Ghanem, A. (2013). Palestinian nationalism: An overview. Israel Studies, 18 (2), 11-29.

Gorny, Y. (1987). Zionism and the Arabs, 1882-1948: A study of ideology. Oxford: Oxford University Press.

Kanafani, G. (1999). Men in the Sun and Other Palestinian Stories. (H. Kilpatrick, Trans.). Boulder, CO: Lynne Rienner. (Original work published 1962)

Kerr, D. (2014, June 27). 'Our goal is to have our freedom': Interview with Iyad Burnat on popular resistance in Bil'in. Mondoweiss. Retrieved from http://mondoweiss.net/2014/06/freedom-interview-resistance/

Khalidi, R. (1997). Palestinian identity: The construction of modern national consciousness. New York: Columbia University Press.

Lavie, S. (2011). Where is the Mizrahi-Palestinian border zone? Interrogating feminist transnationalism through the bounds of the lived. Social Semiotics, 21(1), 67-83.

Likhovski, A. (2010). Post-Post-Zionist historiography. Israel Studies, 15(2), 1-23.

Maira, S. (2013). Jil Oslo: Palestinian hip hop,youth culture, and the youth movement. Washington, DC: Tadween Publishing.

Mamdani, M. (1996). Citizen and subject: Contemporary Africa and the legacy of late colonialism. Princeton, NJ: Princeton University Press.

Mamdani, M. (2001). Beyond Settler and Native as political identities: Overcoming the political legacy of colonialism. Comparative Studies in Society \& History,43(4), 651-664.

Studies in Social Justice, Volume 12, Issue 1, 21-37, 2018 
Massad, J. A. (2006). The persistence of the Palestinian question: Essays on Zionism and the Palestinians. New York: Routledge.

McFarlane, C. (2009). Translocal assemblages: Space, power and social Movements. Geoforum, 40, 561-567.

Ong, A., \& Collier, S. J. (Eds.) (2005). Global assemblages: Technology, politics and ethics as anthropological problems. Malden, MA: Blackwell

Ruedy, J. (1971). Dynamics of land alienation. In I. Abu-Lughod (Ed.), The transformation of Palestine: Essays on the origin and development of the Arab-Israeli conflict (pp. 119-138). Evanston, IL: Northwestern University Press.

Said, E. (1989). Intifada and Independence. In Z. Lockman \& J. Beinin (Eds.), Intifada: The Palestinian uprising against Israeli occupation (pp. 5-22). Toronto: Between The Lines.

Said, E. (1994). Culture and imperialism. New York: Vintage.

Said, E. (1995). The politics of dispossession: The struggle for Palestinian self-determination, 1969-1994. New York: Vintage Books.

Said, E. (1999). Afterword: The consequences of 1948. In E. L. Rogan \& A. Shlaim

(Eds.), The war for Palestine: Rewriting the history of 1948 (pp. 206-219). Cambridge: Cambridge University Press.

Salamanca, O. J., Qato, M., Rabie, K., \& Samour, S. (Eds.). (2012). Past is present: Settler colonialism in Palestine. Settler Colonial Studies, 2 (1). (Journal special issue)

Sayigh, R. (2007). The Palestinians: From peasants to revolutionaries. New York: Zed Books. (Original work published 1979)

Sayigh, Y. (1997). Armed struggle and the search for state: The Palestinian National Movement, 1949-1993. Oxford: Oxford University Press.

Swedenburg, T. (1990). The Palestinian peasant as national signifier. Anthropological Quarterly, $63(1), 18-30$

Yazbak, M. (2000). From poverty to revolt: Economic factors in the outbreak of the 1936 rebellion in Palestine. Middle Eastern Studies, 36 (3), 93-113. 